\title{
Best practices for teachers new to distance education
}

\author{
Linda F. Reed \\ University of Alabama, Birmingham, Alabama, USA \\ Correspondence: Linda F. Reed. Address: University of Alabama, Birmingham, 3212 Colesbury Dr., Birmingham, \\ Alabama 35226, USA. Email: reedl@uab.edu. \\ Received: November 28, 2012 \\ Accepted: December 19, 2012 \\ Online Published: January 24, 2013 \\ DOI : $10.5430 /$ jnep.v3n8p92 \\ URL: http://dx.doi.org/10.5430/jnep.v3n8p92
}

\section{Abstract}

Distance education is an essential teaching strategy in nursing education, and the inclusion of distance accessible education in nursing programs requires that nursing faculty new to this area become knowledgeable of this teaching strategy. Therefore, the purpose of this article is to describe teaching strategies for teachers new to distance education including technology available to support courses, preparation for those courses, early student contact, and socialization into the course. Further, student assignments, evaluation, including peer evaluation, and timely feedback in regard to communication and evaluation are covered.

\section{Key words}

Distance education, Online education, Teachers new to distance education, Novice online educators

\section{Introduction}

Distance accessible courses allow students to continue employment, and on nonworking days to log into an online course and complete course assignments. There is no need to drive to a campus, spend money on gas, or hire a babysitter ${ }^{[1-3]}$. Even when the student lives near enough to a campus to attend onsite classes, there is a good possibility the student will select distance classes. Onsite classroom courses cannot compete with the flexibility of distance accessible courses which have opened doors to thousands of students who could not have received their education without this opportunity ${ }^{[2-7]}$. Therefore, the primary purpose of this article is to provide a source of information to those readers who are new to distance education and who need knowledge to guide them in preparing for and teaching in distance accessible courses.

\subsection{Why the shift to distance accessible education}

The shortage of nursing faculty, and the shortage of clinical nurses are both factors in the shift to distance accessible education at the undergraduate and graduate levels in nursing ${ }^{[2,4]}$. Through innovation and flexibility we can reach more individuals who can be educated as clinical nurses and as nurse educators. The Robert Woods Johnson Foundation and the Institute of Medicine in their report recommended an improved educational system, and seamless academic progression for nursing ${ }^{[8]}$. Distance education courses are a means to accessing more potential students, and implementing flexible, innovative programs provides a means for a seamless academic progression in nursing ${ }^{[9]}$. RN Mobility programs were early adopters of distance education strategies to enable nurses to complete the BSN degree, while remaining employed ${ }^{[3]}$. The BSN degree is also a pipeline for graduates to enroll in Master's programs, and become advanced practitioners or 
nurse educators. Increasing nursing faculty numbers is also critical to admitting more nursing students who can be employed in clinical nursing ${ }^{[2,4]}$.

Many Master's prepared nurses are currently being employed as faculty in nursing programs. The BSN nurses who practiced in a clinical area before entering the Master's program generally have excellent clinical skills, but when employed as nursing faculty, generally have no teaching experience in academia. Therefore, masters faculty, as well as doctorally prepared faculty without teaching experience, will need orientation to distance accessible teaching ${ }^{\text {[10-12] }}$. Further, some experienced traditional classroom teachers have had little development or training in distance teaching. Distance accessible teaching is a fairly new format in many schools of nursing, and the training needs of faculty assigned to distance accessible courses have not kept pace with the implementation of these courses ${ }^{[1,2,13,14]}$. Therefore, few effective role models for distance teaching are available in comparison to traditional classroom models. Additionally, research that documents best practices in distance accessible teaching strategies is limited ${ }^{[11]}$.

Thus, students receive their distance education from faculty who are experts in traditional classroom strategies, but who may be novices in distance education strategies. Students learn to teach by observing faculty in various educational settings, and then incorporate what they learn into their own style of teaching ${ }^{[11]}$. We need to ensure that what students experience in distance accessible courses represents the best practices in this teaching strategy. Nursing programs with educator specialty options have courses that teach students strategies for traditional classroom instruction; many also include some information on laboratory, clinical, simulation, and distance accessible strategies. Distance accessible teaching should be a major focus of a teaching strategies course, because online education is here to stay, and is expected to become more prevalent in the future ${ }^{[1,15]}$. In fact, since distance accessible education is now an integral part of most undergraduate and graduate nursing programs, the content is sufficiently important to warrant teaching it as a distinct course.

\subsection{Technology available to support best practices in distance accessible education}

Best practices in distance accessible courses are more complex than simply transferring your PowerPoint slides, course overview, and content outline to an electronic teaching/learning platform ${ }^{[9,16]}$. Best practices require knowledge of the technology available for distance accessible teaching such as conducting live chats, live texting sessions, and preparing audio, and video narrated lectures ${ }^{[2]}$.

Further, live chat capability in online technology supports collaboration among students who can work in small groups to complete assignments. The instructor can choose to join these small groups, chat with the entire class or chat with students in small groups. Students can also purchase inexpensive cameras or laptops with built in cameras so students and faculty can view one another during chats ${ }^{[12]}$. Threaded discussion capabilities also assist students to know in what areas they need to comment or respond to other students' comments or faculty questions ${ }^{[2]}$. All course materials the students will need during the course can be posted in a content collection area. This content can be separated into modules and made available or some areas can be hidden until strategic points in the term. Content could also include examples of past student work that might be helpful examples to current students. Further, links to appropriate resources such as licensure boards, professional organizations, APA Guidelines, or policies and procedures affecting students should be included. These links allow for large volumes of materials to be accessible at the student's fingertips when needed ${ }^{[17]}$.

In distance accessible teaching, a general discussion board is a common means of communication, and should be available to students. Faculty are able to utilize the discussion board to ask thought provoking questions, and to stimulate discussion. Often there is a rubric, and points are awarded for quality of the student's discussion postings. Remember, however, that with large classes it is time consuming for faculty to monitor and evaluate the quality of every student's posts on the discussion board. Therefore, discussion might be valuable, but awarding of points might not be the best strategy for larger classes. Distance accessible teaching also offers the opportunity for asynchronous and/or synchronous learning ${ }^{[9]}$. In 
synchronous learning the students are in the chat room speaking with faculty or one another in real time. In asynchronous communication, faculty post material, audio, video and/or text, for students to review at their leisure. Some faculty include more synchronous interactions in an attempt to mimic the classroom environment ${ }^{[2]}$. However, with synchronous chats you lose one of the main advantages of distance education, flexibility, as students have to log in at the same time regardless of their schedules. The loss of flexibility can be moderated by archiving live chats for review later by students who cannot be present in real time. However, more meaningful work is likely to be accomplished in small groups as students can more easily coordinate their schedules to develop relationships and learn to work together in a group.

The faculty can ask the students in each group to suggest some days and times when all are available to meet with faculty in real time. The faculty member then selects a convenient day and time from those dates proposed to meet with the students in each group. This author feels that meeting with students in small groups makes it is easier to get to know the students, it feels more personal, and it is easier to interact with each of the group members. Meeting with the entire class makes it difficult for all members of the class to participate in the discussion, and larger blocks of time may be required.

\section{Preparation for distance accessible courses}

Preparation for the course needs to take place before the term begins, including uploading all course information before the first day of class ${ }^{[17]}$. It may be that you plan to release parts of the course at different times. This may be appropriate for some materials, but you need to have certain materials available on the first day. Students are usually anxious about the requirements, and want to know the expectations from the beginning, such things as number of exams, papers, assignments, and due dates. Further, the materials should be detailed and specific as the students must read and understand independently of faculty as they are not in a classroom where supplemental information can be given. All assignments, guidelines, rubrics for grading, and deadlines should be clearly described in the course syllabus. If there are specific instructions related to any requirements those should be available as printable documents. Any consequences of not completing course requirements and/or assignments should be included ${ }^{[18]}$. Even if the course was previously taught, all information should be reviewed for accuracy, and calendar dates or other time sensitive information needs to be updated. If internet links are used, double check them every term to see if they function. Links are often changed, and have to be periodically updated. Nonfunctioning links are very irritating to students, and often result in many emails to faculty.

\subsection{I nitial contact information}

Before the term begins contact incoming students ${ }^{[1]}$. Use your institution's registration process to secure the names of students who are enrolled, including their email addresses. Email addresses should be a part of the student roster as most colleges, universities, and healthcare agencies now assign email addresses to be used by students. Occasionally a student or two will register late, but the majority can be reached before class begins with your roster. Late registrants can be contacted after the term begins. Providing information before the term begins assists students in knowing what to expect, and communicates course details such as the required textbook(s) and necessary technology ${ }^{[17]}$. In your preterm message, identify two or three sources where students can purchase texts in advance so they are ready for assignments when the term begins. This author 's experience is that if students are not informed in advance of the term beginning that it may be two weeks before everyone has purchased the text and can read assignments. Include a description of the distance accessible features utilized in the course, and ask students to respond letting you know if they can access these distance accessible features. Also, notify students of any equipment they will need such as a headset for live chats, camera for video ${ }^{[1,7,12,17]}$. Further, mention that if they have smart phones they may be able to synchronize them to receive course emails in real time. Many students are already using this technology feature.

\subsection{Socialization into a distance accessible course}

The initial contact via email with the course information begins the student's socialization into the course. Also, prepare a welcome video from faculty or an audio message and have it available the first day that the course opens for the term. To 
further enhance socialization, consider creating a treasure hunt, scavenger hunt, or Online Skills 101 Checklist ${ }^{[3]}$. The hunt or checklist list is very useful for novice online students. If your audience is more sophisticated it may not be necessary to this extent. However, there should be some type of orientation. The orientation should include a checklist of things the student should complete before beginning work in the course. Faculty, who are new to online teaching, should also complete the checklist to ensure that they are able to do what is required of students ${ }^{[18]}$. In addition to the student list of activities, faculty should also become acquainted with other skills such as: creating, naming and uploading folders, adding files to folders in Blackboard, placing links to materials in files, uploading video and audio files to Blackboard. If additional technology such as podcasting, vodcasting, is being utilized then orientation must be provided for faculty to these areas. Robina and Anderson confirmed that preparatory experiences for teaching online led to significantly higher online teaching efficacy ${ }^{[5]}$.

Whether or not you include the orientation to course skills list, an opportunity for students to socialize should be created. Ask students to post information about themselves that can be shared with the class ${ }^{[7,12,17]}$. This information can be formatted into a table that includes name, a photo, and other information such as: "are you working and if so in what agency and area; do you have teaching experience, and if so in what area; tell me something that you want to be sure to learn in this course; and is there anything else you would like to communicate about yourself”? This information helps to introduce everyone, and offers students opportunities to network in areas of mutual interest. Faculty can utilize the student information to later divide the class into small work groups or teams that will have diversity based on teaching experience, clinical experience, and career goals ${ }^{[7]}$. Work groups can vary in size depending on the assignment, but the author prefers 5-7 students which was the number utilized by Cole and Kritzer ${ }^{[2]}$. This number is more manageable for students who must coordinate meetings with one another to work in their group chat room. The group or team membership should be determined by faculty so that groups are exposed to diverse clinical backgrounds, experiences, talents, ideas and opportunities for collaboration, and socialization. The groups should remain together for the duration of the term for maximum relationship building ${ }^{[9,17,18]}$.

\section{Assignments and peer evaluation}

Several assignments spread over the term are recommended rather than one or two major assignments that comprise a higher percentage of the grade. Small assignments allow individuals or groups to submit the first assignment and receive feedback for improvement before the majority of points are allocated as opposed to fewer assignments with larger percentages of the grade ${ }^{[2,17,19,20]}$. It is important for students to learn to work as teams or groups, and to learn to hold individual group members accountable for their share of the group work. Students can learn to hold individual group members accountable by completing peer evaluations of members based on objectives such as participation, collaboration, timeliness, and feedback to the group ${ }^{[19,20]}$. Examples of faculty rubrics developed for evaluation of distance accessible discussion boards and assignments are available in the literature ${ }^{[1,12,13,21]}$.

Although the importance of peer evaluations has been documented ${ }^{[7,21,22]}$, few rubrics for student evaluation of individuals within a group were found. Manning and Frisley published their rubric for student evaluation of a group's outcome ${ }^{[21]}$. Wright, Scherb, and Forsyth published a rubric for student self-evaluation of their own participation in online discussions ${ }^{[22]}$. No rubric was found for student evaluation of peers within a group based on the individual's contribution to the group project. Therefore, this author developed a peer evaluation rubric which allows students to individually grade members of the group based on participation and quality of work. Faculty assign an overall group grade, which is averaged with the individual student grades. Therefore, individuals within a group may have different grades depending on how high or low their peers evaluated them on participation and quality of work within the group. Students liked this option as one of their original complaints was that there was always someone who did not do their share of the work, and this strategy allowed them to hold members accountable for their share of the work by contributing to the member's grade for the assignment. 


\section{Timeliness in communication and evaluation}

Email is a fast efficient method to communicate with students. If more than six students are enrolled in a course, it is more efficient to request that students email through the distance accessible course rather than through faculty members' desktop email account. Within the online course, faculty have the capability of emailing a reply to the entire class, a group or an individual. If faculty teach in two distance accessible courses in the same term, keeping messages separated by course in the online learning platform decreases confusion. Regardless of how you reply to emails, it must be done in a timely manner. However, what constitutes timely in the literature ranges from twice a day, every day, to within 48 hours ${ }^{[2,19,20]}$.

As a general rule, during the first two or three weeks of the course, greater faculty oversight of and frequent communications with students clarifies requirements, and facilitates student orientation and success ${ }^{[20,22]}$. Plan to answer messages every day during this time. This strategy results in fewer emails from students, and less time spent explaining requirements later. If faculty delay in responding early on, the number of emails may become overwhelming. Later in the term, respond to emails more frequently around assignment due dates or exams as students usually have many questions at this point. Often, only a few words are required to answer messages, but do not be too blunt as it may appear uncaring. The tone of the message is important ${ }^{[19]}$. If you find that additional information is required, let the student know that you will respond with the information in the next 48 hours. Students want to know the message was received, and that faculty will address their issue. Also, remember that answering messages promptly is highly correlated with student satisfaction with the course ${ }^{[19]}$.

Regardless of the faculty definition of timeliness, the timeframe should be clearly stated in the course. Students need to know what to expect, and faculty need to consistently follow what is stated in the course material. If faculty do not plan to communicate within 48 hours or every day, then post online office hours that state when you are available to answer questions in a live chat room. This arrangement mimics onsite faculty office hours. Some faculty do both, and schedule office hour chats in addition to answering emails within the defined time frame in the syllabus ${ }^{[2,12]}$. Office hours that include live chats allow the faculty to answer questions for a number of students and decreases the need for individual student messages.

It is also very important to return feedback on assignments or quizzes in a timely fashion. The amount of time that faculty will require to grade assignments or exams should also be posted in the course ${ }^{[12,21]}$. The time required to grade assignments is somewhat dependent on the number of students enrolled in the course, and/or length of assignments. However, all assignments should be returned in time for the student to use the feedback to help prepare the next assignment ${ }^{[19]}$. Timely feedback is an essential part of learning, so you should design all assignments so that you are able to provide timely feedback to students. In addition to assigning points and letter grades, comments should be written for all papers and assignments. A common technique is to utilize track changes in Microsoft Word to write comments at points in the document. Another strategy to use if you are grading papers without computer access is to print copies of assignments so that you can read them wherever you are. You can then write comments in the margins of the paper, scan the corrected assignments, and email the corrected documents to the students. This strategy works well with smaller classes, and handwritten comments on the paper are more personal than using the tracking feature of your software ${ }^{[17]}$.

\section{Social media possibilities and other technological innovations for use in online education}

It is widely accepted that our students are technologically savvy and have enthusiastically embraced media platforms such as Facebook, Twitter, Skyping, the Cloud, YouTube, and blogs. Many educators also realize that the acceptance of social media by students has frequently surpassed faculty's proficiency and comfort level in this area. However, faculty must learn to incorporate these technologies appropriately into the classroom in order to maximize learning ${ }^{[23-29]}$. Benefits believed to arise from these strategies are an increased level of interactivity and engagement, along with enhanced 
collaboration and communication skills. Further, these strategies have a strong appeal to students who are a part of the digital generation ${ }^{[27]}$. However, faculty development is needed to assist faculty to evaluate social media and its possibilities in education ${ }^{[2,11,24,30]}$. An example of free development is the Google Geo Teachers Institute which is a seminar designed to teach educators how to use various social media platforms in the classroom ${ }^{[2,19,20]}$. These seminars can be a beginning for faculty development in this area.

\section{Considerations for selection of technology}

Finally, although many technology strategies are available to distance accessible teaching, all should not be used in any one course. Just because a strategy is available does not mean it is the best one for a given course. Think about the objectives of the course that will be taught, and decide which of the distance accessible features are; 1) available to you, 2) available to the students, and 3) appropriate for the content you will teach. Further, in regard to technology requirements, all schools of nursing with distance accessible courses should post on their school webpage information describing the technology required to successfully enroll in distance accessible courses ${ }^{[2]}$. This author has found that even when this information is clearly posted, some enrolled students will not have all the necessary technology features. Consider developing "high tech" and "low tech" strategies for students with dial up internet access in rural areas. Students with dial up technology will not be able to receive streaming video or even large files with pictures. If a student cannot participate in live chats they often can participate in live texting. The technology strategies incorporated into the course should be evaluated against the student's distance accessible technology capability. One option is to post video for the more advanced equipment owners, and also to include narrative material that is accessible to everyone. Using both low tech and high tech versions allows the course material to be available to all students ${ }^{[1]}$.

\section{Summary}

Distance accessible education is critical to meet the needs of today's learner who has many life obligations, but also needs the flexibility to accomplish career goals. This type learning strategy requires rethinking the traditional philosophy of how to teach students. Distance accessible learning is a paradigm shift for many faculty as well as some students ${ }^{[11,14,16]}$. Faculty new to distance education need to accept that this strategy is equivalent to traditional didactic strategies, and is appropriate for nursing education ${ }^{[9]}$, because facilitating the academic development of students who are unable to enroll in traditional onsite academic courses is critical to increasing the number of graduates needed to provide quality healthcare to the increasingly aging population.

\section{References}

[1] Cantrell SW, O’Leary P. Strategies for success in online learning. Nurs Clin North Am. 2008; 43(4): 547-555. PMid:18940411 http://dx.doi.org/10.1016/j.cnur.2008.06.003

[2] Cole JE, Kritzer JB. Strategies for success: teaching an online course. Rural Spec Educ Q. 2009; 28(4): 36-40.

[3] Gyurko CC, Ullmann J. Using online technology to enhance educational mobility. Online J Nurs Inform. 2012; 16(1). Available from: http://ojni.org/issues/?p=1270.

[4] Grady JL. The virtual clinical practicum: an innovative telehealth model for clinical nursing education. Nurs Educ Perspec. 2011; 32(3): 189-194. PMid:21834382 http://dx.doi.org/10.5480/1536-5026-32.3.189

[5] Robinia KA, Anderson, JL. Online teaching efficacy of nurse faculty. J Prof Nurs. 2010; 26(3): 168-175. PMid:20488426 http://dx.doi.org/10.1016/j.profnurs.2010.02.006

[6] Mancuso-Murphy J. Distance education in nursing: an integrated review of online nursing students' experiences with technologydelivered instruction. J Nurs Educ. 2007; 46(6): 252-260. PMid:17580737

[7] Mayne LA, Wu Q. Creating and measuring social presence in online graduate nursing courses. Nurs Educ Perspect. 2011; 32(2): 110-114. PMid:21667793 http://dx.doi.org/10.5480/1536-5026-32.2.110 
[8] Committee on the Robert Wood Johnson Foundation Initiative on the Future of Nursing, at the Institute of Medicine. The future of nursing: leading change, advancing health. Available from:

http://www.iom.edu/Reports/2010/The-Future-of-Nursing-Leading-Change-Advancing-Health.aspx (9 November 2012, date last accessed).

[9] Hoffmann RL, Dudjak LA. From onsite to online: lessons learned from faculty pioneers. J Prof Nurs. 2012; 28(4): 255-258. PMid:22818196 http://dx.doi.org/10.1016/j.profnurs.2011.11.015

[10] Danzey ID, Ea E, Fitzpatrick JJ, Garbutt SJ, Rafferty M, Zychowicz ME. The doctor of nursing practice and nursing education: highlights, potential, and promise. J Prof Nurs. 2011; 27(5): 311-314. PMid:21925464 http://dx.doi.org/10.1016/j.profnurs.2011.06.008

[11] Johnson A. A nursing faculty's transition to teaching online. Nurs Educ Perspect. 2008; 29(1): 17-22. PMid:18330417

[12] Vitale AT. Faculty development and mentorship using selected online asynchronous teaching strategies. J Contin Educ Nurs. 2010; 41(12): 549-556. PMid:20704095 http://dx.doi.org/10.3928/00220124-20100802-02

[13] Blood-Siegfried JE, Short NM, Rapp CG, Hill E, Talbert S, Skinner J, et al. A rubric for improving the quality of online courses. Int J of Nurs Educ Scholarsh. 2008; 5(1): 1-13. PMid:18976231 http://dx.doi.org/10.2202/1548-923X.1648

[14] Paulus TM, Myers CR, Mixer SJ, Wyatt TH, Lee DS, Lee JL. For faculty, by faculty: a case study of learning to teach online. Int J of Nurs Educ Scholarsh. 2010; 7(1): 1-18. PMid:20433420 http://dx.doi.org/10.2202/1548-923X.1979

[15] Wyllie A. Eager 'weavers': designing assessment for online assessment. Nurse Educ Pract. 2011; 11(2): 99-103. PMid:21177143 http://dx.doi.org/10.1016/j.nepr.2010.11.011

[16] Bromley P. Online learning: anywhere anytime education for specialist nursing. Neonatal, Paediatric and Child Health Nursing. 2010; 13(3): 2-6.

[17] Zsohar H, Smith JA. Transition from the classroom to the web: successful strategies for teaching online. Nurs Educ Perspect. 2008; 29(1): 23-28. PMid:18330418

[18] Blake D. What I learned from teaching adult learners online. elearn Magazine. 2009. Available from: http://elearnmag.acm.org/archive.cfm?aid=1692866 (12 November, 2012, date last accessed).

[19] Bonnel W. Improving feedback to students in online courses. Nurs Educ Perspect. 2008; 29(5): 291-294.

[20] Bonnel W, Boehm H. Improving feedback to students online: teaching tips from experienced faculty. J Contin Educ Nurs. 2011; 42(11): 503-509. PMid:21780734 PMid:21780734

[21] Manning ML, Frisby AJ. Multimethod teaching strategies to integrate selected QSEN competencies in a Doctor of Nursing Practice distance education program. Nurs Outlook. 2011; 59(3): 166-173. PMid:21507440 http://dx.doi.org/10.1016/j.outlook.2011.01.001

[22] Wright TL, Scherb CA, Forsyth DM. A rubric for evaluating online discussion contributions of graduate nursing students. Clin Scholars Rev. 2011; 4(1): 5-14. http://dx.doi.org/10.1891/1939-2095.4.1.5

[23] Venable MA. 100 Ways You Should Be Using Facebook in Your Classroom. Available from: http://www.onlinecollege.org/2012/05/21/100-ways-you-should-be-using-facebook-in-your-classroom-updated/ (14 November 2012, date last accessed).

[24] Dubose, C. The social media revolution. Radiol Technol. 2011; 83(2): 112-119. PMid:22106386

[25] Wagner, R. Social media tools for teaching and learning. Athl Train Educ J. 2011; 6(1): 51-52.

[26] Adams L. Using Skype in clinical education. Radiol Technol. 2011; 82(5): 475-477. PMid:21572069

[27] George DR, Dellaserga, C. Use of social media in graduate-level medical humanities education: Two pilot studies from Penn State College of Medicine. Med Teach. 2011; 33: e429-e434. PMid:21774639 http://dx.doi.org/10.3109/0142159X.2011.586749

[28] Wink, DM. Cloud computing. Nurs Educ. 2012; 37(1): 3-540(4): 27

[29] Shaohui W., Lihua J. The application of blog in modern education. 2008 International Conference, Computer Science and Software Engineering. 2008; 4: 1083-1085. http://dx.doi.org/10.1109/CSSE.2008.1443

[30] Byrne, R. Google geo teacher institute. Free Technology for Teachers. Available from: www.freetech4teachers.com/2010/05 (7 November 2012, date last accessed). 